\title{
Gambaran Penyakit Reproduksi Wanita pada Pasien Rawat Inap yang Menggunakan BPJS Kesehatan di Salah Satu Rumah Sakit Kelas A di Jakarta
}

\author{
Description of Female Reproductive System Diseases in Hospitalized \\ BPJS Patients in One Hospital in Jakarta
}

\author{
Cicih Opitasari ${ }^{1}$ \\ ${ }^{1)}$ Pusat Penelitian dan Pengembangan Sumber Daya dan Pelayanan Kesehatan, Jalan Percetakan Negara No. 29 Jakarta \\ 10560, Indonesia \\ Korespondensi: vitasari2010@gmail.com
}

Submitted: 29 April 2020, Revised: 23 Juli 2020, Accepted: 12 Agustus 2020

https://doi.org/10.22435/jpppk.v4i2.4504

\begin{abstract}
Abstrak
Penyakit reproduksi menjadi beban berat dan memiliki dampak besar terhadap kesehatan dan kualitas hidup wanita. Tulisan ini bertujuan untuk mengetahui gambaran penyakit kelompok reproduksi wanita pada pasien Badan Penyelenggaraan Jaminan Sosial (BPJS) Kesehatan yang dirawat inap di rumah sakit. Penelitian ini dilakukan dengan menggunakan desain potong lintang di salah satu rumah sakit (RS) pemerintah di Jakarta. Data penelitian menggunakan seluruh data klaim rawat inap pasien BPJS Kesehatan periode JanuariDesember 2017 yang di dapatkan dari aplikasi E-Klaim INA-CBGs. Semua pasien wanita yang dirawat inap dan tergolong ke dalam kelompok penyakit reproduksi wanita berdasarkan casemix main groups dianalisis secara deskriptif. Total pasien pada kelompok ini sebanyak 1220, sedangkan jumlah kunjungan adalah 1528 kunjungan. Sebanyak 308 kunjungan merupakan kasus readmisi (tingkat readmisi 20,2\%). Usia pasien terbanyak pada kelompok umur 35-44 tahun, rata-rata 39 tahun. Sebagian besar dirawat di kelas 3 dan memiliki tingkat keparahan level 1 dengan lama perawatan rata-rata 5,5 hari. Pasien dengan indikasi rawat ICU sebesar $6,6 \%$ dan hampir semua pasien dipulangkan atas persetujuan dokter. Diagnosis utama dan sekunder terbanyak masing-masing adalah observasi suspek neoplasma maligna dan anemia. Rerata klaim INA-CBGs pada penyakit reproduksi wanita masih lebih rendah dari tarif RS, kecuali pada gangguan post partum berat dan antepartum berat.
\end{abstract}

Kata kunci : penyakit reproduksi wanita, rawat inap, BPJS Kesehatan, INA-CBGs

\begin{abstract}
Reproductive morbidity becomes a major burden and has a large impact on women's health and their quality of life. This paper aims to address the diseases of a female reproductive group in hospitalized BPJS Kesehatan patients. This study was conducted using a cross-sectional design in one government hospital in Jakarta. The study used all hospital claim data for BPJS Kesehatan patients from January to December 2017 that was taken from the E-Claim INA-CBGs application. All-female patients who were hospitalized and classified as female reproductive disease groups based on case-mix main groups were analyzed descriptively. The total number of patients in this group was 1220, while the number of visits was 1528 visits. A total of 308 visits were readmission cases (readmission rate of 20.2\%). Most of the patients were aged 35-44 years with an average was 39 years. The majority of the patients were treated in the third class and had severity level 1, the mean length of stay was 5.5 days. The patients who had ICU indication were $6.6 \%$ and almost all patients were discharged with the physician's approval. The most common primary and secondary diagnoses were observations of suspected malignant neoplasms and anemia respectively. The mean of INA-CBG claims in female reproductive diseases was still lower than hospital rates, except in severe postpartum and antepartum disorders.
\end{abstract}

Keywords: female reproductive diseases, hospitalized, BPJS Kesehatan 


\section{Pendahuluan}

Penyakit reproduksi merupakan suatu disfungsi atau gangguan pada saluran reproduksi, yang disebabkan oleh berbagai faktor termasuk kehamilan, aborsi, persalinan, atau perilaku seksual. ${ }^{1}$ Saluran reproduksi wanita terdiri dari ovarium, uterus, serviks, dan vagina. ${ }^{2}$ Sistem reproduksi wanita memiliki sistem yang kompleks. ${ }^{3}$ Morfologi dan fungsi saluran reproduksi terus berubah sesuai dengan usia dan fase siklus estrus atau menstruasi. ${ }^{2}$ Gangguan pada sistem reproduksi wanita relatif sering terjadi, seperti di Amerika Serikat, di mana $12 \%$ wanita usia 15-44 tahun mengalami gangguan fekunditas (kemampuan untuk bereproduksi). Gangguan pada sistem reproduksi wanita menjadi beban berat dan dapat berdampak buruk pada kesehatan dan kualitas hidup wanita. ${ }^{1,4}$ Misalnya, endometriosis dan mioma uterus (fibroid), dan adenomiosis uterus dapat menyebabkan nyeri dan perdarahan menstruasi yang berlebihan. ${ }^{4}$ Penyakit reproduksi bila tidak diobati atau dirawat dengan benar dapat menimbulkan gejala sisa jangka panjang yang berat. $^{5}$

Gangguan pada sistem reproduksi wanita dapat terjadi akibat penyakit pada organ lain yang fungsinya memengaruhi organ reproduksi (misal, otak, hipotalamus, hipofisis, tiroid, adrenal, ginjal, hati). Sebaliknya, gangguan pada sistem reproduksi dapat menyebabkan gangguan pada jaringan lain. ${ }^{6}$ Selama usia reproduksi, kelainan yang sering muncul berupa perubahan menstruasi, nyeri panggul, atau kemandulan. Kanker yang timbul di jaringan reproduksi lebih sering terjadi pada usia reproduksi akhir atau menopause dengan angka kematian yang tinggi dan insiden metastasis yang tinggi saat didiagnosis. ${ }^{6}$

Tren global penyakit reproduksi secara keseluruhan sulit dipastikan, tetapi banyak penelitian menunjukkan bahwa banyak indikator pada reproduksi wanita menurun selama setengah abad terakhir. ${ }^{7}$ Di Bangladesh, pada 370 perempuan yang pernah menikah, sebanyak $46,76 \%$ memiliki satu atau lebih gejala gangguan/masalah kesehatan reproduksi. ${ }^{8}$ Di Indonesia, berdasarkan hasil riset penyakit tidak menular, dilaporkan prevalensi tumor payudara pada kelompok usia 25-34 tahun sebanyak 7,8 persen, meningkat menjadi sekitar 8,5 persen pada kelompok usia 45-54 tahun. Sementara dari pemeriksaan Inspeksi Visual Asetat (IVA) ditemukan sebanyak 7,0 persen yang mengalami lesi prakanker serviks (IVA positif). Lesi prakanker serviks paling banyak ditemukan pada kelompok umur 25-34 tahun $(8,3 \%){ }^{9}$ Selain itu, angka kematian ibu di Indonesia juga masih tinggi. ${ }^{10}$ Sebagai upaya untuk memenuhi kebutuhan kesehatan masyarakat yang layak, maka sesuai dengan amanat UndangUndang No. 40 Tahun 2004 tentang Sistem Jaminan Sosial Nasional dan Undang-Undang No. 24 Tahun 2011 tentang BPJS Kesehatan ditetapkan bahwa operasional BPJS Kesehatan dimulai sejak tanggal 1 Januari 2014. ${ }^{11}$ Bahkan peserta BPJS Kesehatan mendapat pelayanan pemeriksaan penunjang skrining kesehatan reproduksi seperti pemeriksaan IVA dan Pap smear. ${ }^{11}$ Tulisan ini bertujuan untuk mengetahui gambaran penyakit kelompok reproduksi wanita pada pasien BPJS Kesehatan yang dirawat inap di rumah sakit. Dengan demikian pelayanan kesehatan reproduksi yang tercakup dalam skema Jaminan Kesehatan Nasional (BPJS Kesehatan) dapat ditingkatkan.

\section{Metode}

Penelitian ini dilakukan dengan menggunakan desain potong lintang di salah satu rumah sakit (RS) pemerintah di Jakarta. Data penelitian menggunakan seluruh data klaim rawat inap pasien-pasien BPJS Kesehatan pada periode Januari hingga Desember 2017 yang didapatkan dari aplikasi E-Klaim INA-CBGs. Kriteria inklusi artikel adalah semua pasien wanita yang dirawat inap dan tergolong ke dalam kelompok penyakit sistem reproduksi wanita berdasarkan casemix main groups.

Data penelitian yang dikumpulkan dalam studi ini meliputi umur, kelas rawat, lama rawat, tingkat keparahan penyakit, status keluar pasien, diagnosis utama menurut kode ICD 10, diagnosis sekunder menurut kode ICD 10, frekuensi kasus, dan tarif menurut kode INA-CBGs.

Umur (tahun) ditampilkan dalam ratarata dan dibagi menjadi 6 kelompok yaitu $<15$, $15-24,25-34,35-44,45-55, \geq 55$. Kelas perawatan dikelompokkan menjadi kelas 1, 2 dan 3. Tingkat keparahan penyakit dibagi menjadi tingkat keparahan I (tanpa komplikasi atau komorbid), II (dengan mild komplikasi dan komorbid), III (dengan 
major komplikasi dan komorbid berat). ${ }^{12}$ Tingkat keparahan penyakit muncul secara otomatis pada aplikasi software grouper INA-CBGs ketika petugas memasukkan diagnosis primer dan sekunder. Lama rawat (hari) ditampilkan dalam rata-rata dan dibagi menjadi 2 kategori $: \leq 5$ dan $>6$. ICU indikator di bagi menjadi 2 kategori yaitu ya (jika pasien dimasukkan ke dalam ICU selama episode perawatan) dan tidak. Status keluar pasien dari RS dikelompokkan menjadi 4 : atas permintaan dokter (APD), atas permintaan sendiri (APS), dirujuk dan meninggal. Diagnosis utama dan diagnosis sekunder berdasarkan ICD 10 ditampilkan dalam frekuensi. Pengelompokkan kasus dibagi berdasarkan kode dan deskripsi INA-CBGs. Tarif INA-CBGs RS disajikan dalam rata-rata dan standar deviasi.

Selanjutnya data dianalisis secara deskriptif dengan menggunakan software SPSS versi 16. Penelitian ini telah mendapatkan persetujuan etik dari komite etik Fakultas Kesehatan Masyarakat, Universitas Indonesia dengan nomor surat: 564/ UN2.F10/PPM.00.02/20.

\section{Hasil}

Total pasien BPJS Kesehatan pada kelompok sistem reproduksi wanita sebanyak 1220 , sedangkan jumlah kunjungannya adalah 1528 kunjungan. Sebanyak 308 kunjungan merupakan kasus readmisi sehingga tingkat readmisi/readmission rate $20,2 \%$. Tabel 1 menunjukkan pasien terbanyak berada pada kelompok umur 35-44 tahun dan 25-34 tahun dengan rata-rata pasien berusia 39 tahun. Sebagian besar pasien dirawat di kelas 3 dengan lama perawatan terbanyak $\leq 5$ hari, rata-rata 5,5 hari. Pasien lebih banyak memiliki tingkat keparahan level 1 , sedangkan pasien dengan indikasi rawat ICU $6,6 \%$ dan hampir semua pasien $(97,8 \%$ ) dipulangkan atas persetujuan dokter. Sementara jumlah pasien yang meninggal sebesar 1,9\%.

Sepuluh jumlah kasus terbanyak pada kelompok gangguan sistem reproduksi wanita ditunjukkan pada Tabel 2 di bawah ini. Kasus suspek tumor ganas/kanker merupakan diagnosis terbanyak diikuti dengan persalinan palsu pada kehamilan sebelum 37 minggu. Berbagai kelainan pada uterus, kanker ovarium, dan serviks masuk ke dalam sepuluh besar kasus terbanyak. Sementara untuk diagnosis sekunder yang ditunjukkan pada Tabel 3 di dominasi
Tabel 1. Karakteristik Pasien BPJS Kesehatan dengan Gangguan Sistem Kesehatan Reproduksi yang Dirawat Inap

\begin{tabular}{|c|c|c|c|}
\hline Variabel & N (1220) & Persen & $\begin{array}{l}\text { Rata - } \\
\text { Rata }\end{array}$ \\
\hline \multicolumn{4}{|l|}{$\begin{array}{l}\text { Kelompok Umur } \\
\text { (tahun) }\end{array}$} \\
\hline$<15$ & 12 & 1,0 & 39,2 \\
\hline $15-24$ & 128 & 10,5 & \\
\hline $25-34$ & 322 & 26,4 & \\
\hline $35-44$ & 390 & 32,0 & \\
\hline $45-54$ & 218 & 17,9 & \\
\hline$\geq 55$ & 150 & 12,3 & \\
\hline \multicolumn{4}{|l|}{ Kelas Rawat } \\
\hline 1 & 197 & 16,1 & \\
\hline 2 & 337 & 27,6 & \\
\hline 3 & 686 & 56,2 & \\
\hline \multicolumn{4}{|l|}{ Lama Rawat (hari) } \\
\hline$\leq 5$ & 821 & 67,3 & 5,5 \\
\hline$>6$ & 399 & 32,7 & \\
\hline \multicolumn{4}{|l|}{ Tingkat Keparahan } \\
\hline I & 890 & 73,0 & \\
\hline II & 307 & 25,2 & \\
\hline III & 23 & 1,9 & \\
\hline \multicolumn{4}{|l|}{ Indikator ICU } \\
\hline Tidak & 1140 & 93,4 & \\
\hline Ya & 80 & 6,6 & \\
\hline \multicolumn{4}{|l|}{ Status Keluar } \\
\hline Atas persetujuan dokter & 1193 & 97,8 & \\
\hline Atas permintaan sendiri & 4 & 0,3 & \\
\hline Meninggal & 23 & 1,9 & \\
\hline
\end{tabular}

oleh diagnosis anemia, baik anemia yang tidak spesifik, anemia pada keadaan neoplastic / kanker. Ada juga anemia pada kehamilan, persalinan dan masa nifas. Hipertensi dan Diabetes Melitus (DM) juga masuk ke dalam sepuluh penyakit penyerta / diagnosis sekunder terbanyak.

Tabel 4 menunjukkan bahwa berdasarkan deskripsi INA-CBGs, kunjungan terbanyak adalah tindakan / prosedur pada rahim dan adnexa dengan tingkat keparahan ringan atau level I sebanyak $35,8 \%$, diikuti dengan tindakan / prosedur pada rahim dan adnexa dengan tingkat keparahan sedang / level II sebesar 13,7\%. Dalam hal tarif INACBGs, prosedur pada rahim dan adnexa dengan tingkat keparahan level III (berat) merupakan kasus 
Tabel 2. Sepuluh Diagnosis Utama Terbanyak dengan Kode ICD 10 menurut Jumlah Kunjungan

\begin{tabular}{|c|c|c|c|}
\hline Kode ICD 10 & Deskripsi Kode & $\mathbf{N}$ & $\%$ \\
\hline $\mathrm{Z} 03.1$ & Observation for suspected malignant neoplasm & 112 & 7,3 \\
\hline $\mathrm{O} 47.0$ & False labour before 37 completed weeks of gestation & 100 & 6,5 \\
\hline N80.0 & Endometriosis of uterus & 93 & 6,1 \\
\hline C56 & Malignant neoplasm of ovary & 87 & 5,7 \\
\hline N85.8 & $\begin{array}{l}\text { Other specified noninflammatory disorders of uterus (Atrophy of uterus, ac- } \\
\text { quired;Fibrosis of uterus) }\end{array}$ & 73 & 4,8 \\
\hline D25.9 & Leiomyoma of uterus, unspecified & 72 & 4,7 \\
\hline $\mathrm{D} 25.1$ & Intramural leiomyoma of uterus & 65 & 4,3 \\
\hline $\mathrm{D} 27$ & Benign neoplasm of ovary & 61 & 4 \\
\hline C53.9 & Malignant neoplasm : cervix uteri, unspecified & 50 & 3,3 \\
\hline N85.0 & Endometrial glandular hyperplasia & 44 & 2,9 \\
\hline
\end{tabular}

Tabel 3. Sepuluh Diagnosis Sekunder Terbanyak dengan Kode ICD 10 menurut Jumlah Kunjungan

\begin{tabular}{|c|c|c|c|}
\hline Kode ICD & Deskripsi & $\mathbf{N}$ & $\%$ \\
\hline D64.9 & Anaemia, unspecified & 148 & 8,5 \\
\hline D63.0 & Anaemia in neoplastic disease & 141 & 8,1 \\
\hline $\mathrm{O} 47.0$ & False labour before 37 completed weeks of gestation & 83 & 4,8 \\
\hline N85.8 & Other specified noninflammatory disorders of uterus & 73 & 4,2 \\
\hline O99.0 & Anaemia complicating pregnancy, childbirth and the puerperium & 62 & 3,6 \\
\hline $\mathrm{Z} 03.8$ & Observation for other suspected diseases and conditions & 53 & 3,1 \\
\hline $\mathrm{I} 10$ & Essential (primary) hypertension & 47 & 2,7 \\
\hline N73.6 & Female pelvic peritoneal adhesions & 43 & 2,5 \\
\hline E11.9 & Non-insulin-dependent diabetes mellitus without complications & 38 & 2,2 \\
\hline $\mathrm{O} 34.2$ & Maternal care due to uterine scar from previous surgery & 37 & 2,1 \\
\hline
\end{tabular}

dengan klaim INA-CBGs paling besar rata-rata Rp18,268,450 diikuti dengan operasi pengangkatan rahim dan vulva radikal dan eviscerasi dengan tingkat keparahan level I rata-rata $\mathrm{Rp} 18,153,650$. Kasus dengan klaim INA-CBGs terendah adalah kasus gangguan postpartum dengan tingkat keparahan I (ringan ) rata-rata sebesar Rp1,650,671. Pada kelompok penyakit ini terlihat bahwa tarif INA-CBGs hampir semuanya masih berada di bawah tarif RS, kecuali pada gangguan postpartum berat dan antepartum berat yang berada di atas tarif RS.

\section{Pembahasan}

Kasus pada kelompok penyakit reproduksi wanita tampak meningkat seiring dengan bertambahnya usia, dan terbanyak pada usia 35-44 tahun. Penuaan merupakan proses biologis kompleks yang menyebabkan perubahan pada tubuh. ${ }^{13}$
Penuaan manusia dimulai pada usia 30-40 tahun. ${ }^{14}$. Organ reproduksi merupakan organ yang paling awal terdampak terkait perubahan usia. Adanya penuaan seluler dan organik diduga berkontribusi terhadap penurunan fungsi reproduksi terkait usia. ${ }^{13}$ Penyebab penuaan masih belum jelas, tetapi oksigen reaktif spesies dan kerusakan mitokondria adalah dua teori yang dapat diterima. ${ }^{14}$ Konsep inflamasi yang berhubungan dengan usia berperan dalam patologi penyakit reproduksi yang merupakan kondisi peradangan sistemik yang diinduksi oleh fenotip sekretori terkait penuaan atau systemic inflammatory state induced by the senescence-associated secretory phenotype $(S A S P) .{ }^{13}$ Adanya peradangan kronis mempercepat disfungsi reproduksi di ovarium, tuba fallopi, dan uterus. ${ }^{14}$

Kelas perawatan terbanyak pada kelas 3, penemuan ini tidak hanya pada kasus penyakit reproduksi saja. Heniwati melaporkan untuk kasus 
Tabel 4. Frekuensi Kasus dan Tarif menurut INA-CBGs

\begin{tabular}{|c|c|c|c|c|c|c|}
\hline \multirow{2}{*}{ Deskripsi INA-CBG } & \multirow{2}{*}{$\begin{array}{c}N \\
(1528)\end{array}$} & \multirow{2}{*}{$\%$} & \multicolumn{2}{|c|}{ Tarif INA-CBGs } & \multicolumn{2}{|c|}{ Tarif RS } \\
\hline & & & Mean & SD & Mean & SD \\
\hline Prosedur pada rahim dan adnexa (ringan) & 547 & 35,8 & 13.079 .373 & 1.793 .553 & 19.568 .614 & 6.998 .06 \\
\hline Prosedur pada rahim dan adnexa (sedang) & 210 & 13,7 & 16.372 .722 & 2.267 .196 & 24.552 .382 & 12.559 .648 \\
\hline $\begin{array}{l}\text { Prosedur dilatasi, kuret, intrauterine \& } \\
\text { servik (ringan) }\end{array}$ & 119 & 7,8 & 3.449 .829 & 415.54 & 6.595 .768 & 2.383 .285 \\
\hline Gangguan antepartum (ringan) & 99 & 6,5 & 2.426 .308 & 278.464 & 3.946 .637 & 2.251 .810 \\
\hline $\begin{array}{l}\text { Prosedur pada vagina, servik \& vulva } \\
\text { (ringan) }\end{array}$ & 92 & 6,0 & 7.485 .437 & 1.116 .103 & 12.840 .413 & 6.751 .778 \\
\hline Persalinan palsu (ringan) & 75 & 4,9 & 1.807 .523 & 220.229 & 3.388 .952 & 1.871 .153 \\
\hline $\begin{array}{l}\text { Gangguan menstruasi \& sistem reproduksi } \\
\text { wanita lain-lain (ringan) }\end{array}$ & 49 & 3,2 & 3.249 .849 & 402.987 & 5.169 .255 & 4.310 .370 \\
\hline $\begin{array}{l}\text { Gangguan menstruasi \& sistem reproduksi } \\
\text { wanita lain-lain (sedang) }\end{array}$ & 47 & 3,1 & 6.279 .879 & 870.878 & 9.706 .264 & 9.711 .190 \\
\hline Prosedur aborsi (ringan) & 40 & 2,6 & 3.154 .530 & 339.05 & 6.171 .743 & 3.548 .664 \\
\hline $\begin{array}{l}\text { Prosedur dilatasi, kuret, intrauterine \& } \\
\text { servik (sedang) }\end{array}$ & 36 & 2,4 & 3.663 .147 & 466.386 & 9.123 .678 & 2.652 .775 \\
\hline Tumor sistem reproduksi wanita (sedang) & 33 & 2,2 & 8.102 .521 & 1.167 .463 & 13.189.961 & 9.362 .528 \\
\hline Persalinan palsu (sedang) & 29 & 1,9 & 2.705 .234 & 233.206 & 4.333 .797 & 2.050 .629 \\
\hline Gangguan antepartum (sedang) & 26 & 1,7 & 4.328 .473 & 438.265 & 6.947 .962 & 4.750 .563 \\
\hline Gangguan pospartum (ringan) & 21 & 1,4 & 1.650 .671 & 71.357 & 3.482 .900 & 1.216 .816 \\
\hline $\begin{array}{l}\text { Prosedur pada vagina, servik \& vulva } \\
\text { (sedang) }\end{array}$ & 15 & 1,0 & 11.562 .220 & 1.709 .734 & 20.325 .820 & 13.295 .855 \\
\hline Abortus (ringan) & 13 & 0,9 & 1.884 .877 & 227.844 & 3.444 .769 & 1.465 .731 \\
\hline Prosedur aborsi (sedang) & 12 & 0,8 & 3.540 .975 & 336.609 & 11.263 .967 & 3.861 .648 \\
\hline Gangguan pospartum (sedang) & 11 & 0,7 & 4.389 .700 & 412.903 & 9.366 .618 & 6.607 .812 \\
\hline Prosedur pada rahim dan adnexa (berat) & 10 & 0,7 & 18.268 .450 & 1.750 .584 & 34.956 .610 & 23.764 .485 \\
\hline Tumor sistem reproduksi wanita (berat) & 7 & 0,5 & 15.743 .086 & 2.223 .249 & 38.080 .643 & 17.069 .114 \\
\hline Infeksi sistem reproduksi wanita (ringan) & 5 & 0,3 & 4.420 .900 & 432.427 & 4.869 .160 & 1.934 .755 \\
\hline Abortus (sedang) & 5 & 0,3 & 2.545 .760 & 258.196 & 7.729 .480 & 6.854 .047 \\
\hline Infeksi sistem reproduksi w & 4 & 0,3 & 6.292 .125 & 599.25 & 10.191 .500 & 4.599 .904 \\
\hline $\begin{array}{l}\text { Gangguan menstruasi \& sistem reproduksi } \\
\text { wanita lain-lain (berat) }\end{array}$ & 4 & 0,3 & 9.117 .875 & 1.657 .750 & 18.829 .450 & 20.400 .594 \\
\hline $\begin{array}{l}\text { Operasi pengangkatan Rahim dan vulva } \\
\text { radikal dan eviscerasi (sedang) }\end{array}$ & 3 & 0,2 & 17.853 .033 & 1.932 .680 & 31.169 .967 & 12.408 .590 \\
\hline Tumor sistem reproduksi wanita (ringan) & 3 & 0,2 & 100 & 556.854 & 4.302 .400 & 1.920 .418 \\
\hline Gangguan pospartum (berat) & 3 & 0,2 & 9.256 .600 & 1.886 .203 & 5.166 .733 & 3.573 .434 \\
\hline $\begin{array}{l}\text { Operasi pengangkatan Rahim dan vulva } \\
\text { radikal dan eviscerasi (ringan) }\end{array}$ & 2 & 0,1 & 18.153 .650 & 1.974 .879 & 22.170 .800 & 6.413 .741 \\
\hline $\begin{array}{l}\text { Prosedur dilatasi, kuret, intrauterine \& } \\
\text { servik (berat) }\end{array}$ & 2 & 0,1 & 4.157 .150 & 534.502 & 16.077 .200 & 13.155 .439 \\
\hline Abortus mengancam (sedang) & 2 & 0 , & & 388.131 & 4.555 .750 & 2.018 .861 \\
\hline Prosedur pada tuba falc & 1 & 0 , & 3.330 .600 & NA & 10.184 .600 & $\mathrm{~N}$ \\
\hline $\begin{array}{l}\text { Prosedur pada tuba falopii dengan endo- } \\
\text { skopi (ringan) }\end{array}$ & 1 & 0,1 & 3.423 .600 & NA & 13.637 .400 & \\
\hline Abortus mengancam (ringan) & 1 & 0,1 & 2.30 & NA & 4.454 .900 & $\mathrm{~N}$ \\
\hline Gangguan antepartum (berat) & 1 & 0,1 & 9.018 .200 & NA & 4.931 .100 & $\mathrm{~N}$ \\
\hline
\end{tabular}

penyakit katastropik sebagian besar $(85,4 \%)$ pasien BPJS Kesehatan, baik di Provinsi DKI Jakarta maupun di Provinsi Nusa Tenggara Timur, dirawat di kelas $3 .{ }^{15}$ Menurut Rathomi dkk, setelah program Jaminan Kesehatan Nasional (JKN) diterapkan, utilisasi pelayanan kesehatan untuk kasus kanker 
serviks meningkat, kasus yang terdiagnosis juga cenderung semakin muda dan terdeteksi lebih awal. ${ }^{16}$ Hal ini juga terlihat dari tingkat keparahan penyakit pada kasus penyakit reproduksi, di mana $73 \%$ berada pada level 1 yaitu tanpa komplikasi/ komorbid, sebagian besar kasus $(93,4 \%)$ tidak ada indikasi untuk dirawat di ICU dan 97,8\% pasien pulang atas persetujuan dokter. Artinya pasien mendapat akses pelayanan lebih dini sehingga angka kesembuhannya juga tinggi.

Berdasarkan ICD 10, diagnosis utama terbanyak ditemukan pada kasus suspek tumor ganas/kanker. Sementara diagnosis sekunder terbanyak adalah anemia tidak spesifik. Perempuan memiliki risiko lebih besar mengalami anemia dibandingkan pria hampir di semua wilayah geografis dan di sebagian besar kelompok umur. ${ }^{17}$ Secara global, kekurangan zat besi merupakan penyebab utama terbanyak terjadinya anemia, namun banyak penyakit juga dihubungkan dengan kejadian anemia ${ }^{17,}{ }^{18}$. Pada studi ini anemia yang menyertai keganasan merupakan diagnosis sekunder terbanyak kedua, hal ini bisa juga disebabkan karena banyaknya kasus suspek tumor ganas atau kanker yang teridentifikasi.

Berdasarkan kode dan deskripsi INACBGs, prosedur pada rahim dan adnexa ringan merupakan tindakan terbanyak pada kelompok penyakit ini. Mengingat RS ini adalah RS kelas A, maka tingkat keparahan penyakit menjadi hal yang harus diperhatikan. Mengacu pada sistem rujukan berjenjang, RS kelas A adalah rujukan akhir dari sistem pelayanan rujukan rumah sakit. Sehingga kasus-kasus penyakit yang dirujuk adalah kasus-kasus penyakit pada severity level (tingkat keparahan) 2 atau 3. Kajian yang dilakukan oleh Thabrany dkk. melaporkan bahwa alasan pasien dirujuk langsung ke RS kelas A tertinggi karena permintaan kontrol sebanyak $76 \%$ sedangkan untuk keperluan diagnostik sebanyak $16 \%$. Salah satu jenis diagnosis yang dirujuk antara lain beberapa prosedur operasi. Jika demikian maka secara prinsip memang memiliki indikasi kebutuhkan untuk dirujuk ke RS Kelas A. ${ }^{19}$ Dalam hal tarif INA-CBGs, terlihat bahwa pada gangguan postpartum dan antepartum berat rata-rata klaim berada di atas rata-rata tarif RS sedangkan yang lain sebaliknya. Namun demikian tidak berarti bahwa RS mengalami kerugian, karena klaim INA-CBGs harus dilihat secara komprehensif untuk seluruh kelompok penyakit. Handayani dkk. melaporkan bahwa biaya full cost rawat inap di RS Kelas A, di ruang rawat inap kelas 1, 2 dan 3 masih lebih rendah dari perhitungan tarif INA-CBGs secara keseluruhan. ${ }^{20}$ Secara umum, hasil perhitungan unit cost dengan metode step down di 84 RS Umum BLU/BLUD baik untuk rawat inap, maupun rawat jalan lebih rendah dari tarif INA-CBGs, sehingga tarif INA-CBGs yang diberlakukan masih layak dan dapat diterapkan. ${ }^{20}$

\section{Kesimpulan}

Penyakit reproduksi wanita yang paling banyak ditemukan pada pasien BPJS Kesehatan rawat inap di RS ini adalah observasi suspek neoplasma maligna/keganasan dengan penyakit penyerta terbanyak adalah anemia, namun untuk severity level RS sebagai kelas A sebagian besar masih level I. Rerata klaim INA-CBGs lebih rendah dari rerata tarif rumah sakit.

\section{Saran}

Sistem rujukan perlu di evaluasi lagi bersama dengan jejaring RS dan fasilitas kesehatan primer sehingga kasus dengan severity level 2 dan 3 bisa mencapai persentase lebih tinggi lagi sesuai dengan kompetensi RS sebagai RS kelas A. RS menyusun dan menggunakan clinical pathway serta melakukan perhitungan unit cost untuk kendali mutu dan kendali biaya.

\section{Ucapan Terima Kasih}

Tulisan ini merupakan bagian dari tesis saya, oleh karena itu saya mengucapkan terima kasih kepada Kepala Puslitbang Sumber Daya dan Pelayanan Kesehatan yang telah memberikan ijin tugas belajar, Badan PPSDM yang telah mendanai penelitian ini melalui tugas belajar, dan pihak RS yang telah memfasilitasi penelitian ini.

\section{Kontribusi Penulis}

Melakukan proses pengumpulan data, menuliskan draft artikel, dan menyiapkan referensi. Penulis membaca dan menyetujui artikel final ini.

\section{Daftar Rujukan}

1. Tehrani FR, Simbar M, Abedini M. Reproductive 
morbidity among Iranian women; issues often inappropriately addressed in health seeking behaviors. BMC Public Health. 2011;11:1-8. doi:10.1186/1471-2458-11-863

2. Gopinath C. Toxicology and pathology of female reproductive tract. Cell Biol Toxicol. 2013;29(3):131-41. doi:10.1007/s10565-0139244-3

3. Center for Diseases Control and Prevention (CDC). Women's reproductive health. [Internet]. [diakses 9 Juli 2020]. Tersedia pada : https:// www.cdc.gov/reproductivehealth/womensrh/ index.htm

4. Luderer U, Eskenazi B, Hauser R, Korach KS, McHale CM, Moran F, et al. Proposed Key Characteristics of Female Reproductive Toxicants as an Approach for Organizing and Evaluating Mechanistic Data in Hazard Assessment. Environ Health Perspect. 2019;127(7):1-14. doi:10.1289/EHP4971

5. Balsara Z, Wu I, Marsh D, Ihsan A, Nazir R, Owoso E, et al. Reproductive tract disorders among Afghan refugee women attending health clinics in Haripur, Pakistan. Journal of Health, Population, and Nutrition. 2010;28(5):501-8. doi:10.3329/jhpn.v28i5.6159

6. Erika B. Johnston-MacAnanny BGP, Robert N. Taylor. Disorders of The Female Reproductive Tract. Pathophysiology of Disease: an Introduction to Clinical Medicine. New York: McGraw-Hill Education; 2018.

7. Crain DA, Janssen SJ, Edwards TM, Heindel J, Ho SM, Hunt P, et al. Female reproductive disorders: the roles of endocrine-disrupting compounds and developmental timing. Fertil Steril. 2008;90(4):911-40. doi:10.1016/j. fertnstert.2008.08.067

8. Rani V, Dixit AM, Kumar S, Singh NP, Jain PK, Peeyush K. Reproductive Morbidity Profile Among Ever Married Women (15-44) Years of Rural Etawah District, Uttar Pradesh: A crossSectional Study. Community Med. 2016;7(1):3540.

9. Indonesia, Kementerian Kesehatan. Riset Penyakit Tidak Menular: Tumor Payudara dan Lesi Prakanker Serviks Jakarta. [Internet]. [diakses 17 Juli 2020]. Tersedia pada: http:// labmandat.litbang.kemkes.go.id/riset-badan- litbangkes/menu-riskesnas/menu-rikus/424rptm-2016 -

10. Indonesia, Kementerian Perencanaan Pembangunan Nasional (PPN)/Badan PerencanaanPembangunanNasional(Bappenas). Roadmap of SDGs Indonsia towards 2030. Jakarta. [Internet]. [diakses 17 Juli 2020]. Tersedia pada: http://sdgsindonesia.or.id/

11. Indonesia, Badan Penyelenggara Jaminan Sosial (BPJS) Kesehatan. Panduan Praktis Adminsitrasi Klaim Fasilitas Kesehatan BPJS Kesehatan. Jakarta. [Internet]. [diakses 20 Juli 2020]. Tersedia pada: https://www.bpjskesehatan.go.id

12. Indonesia, Kementerian Kesehatan. Permenkes No. 76 tahun 2016 tentang Pedoman INA-CBG dalam pelaksanaan jaminan kesehatan.

13. Shirasuna K, Iwata $\mathrm{H}$. Effect of aging on the female reproductive function. Contracept Reprod Med. 2017;2:1-8. doi:10.1186/s40834017-0050-9

14. Haroun HSW. Aging of Reproductive SystemsA Review Article. Interventions in Gynaecology and Women's Healthcare. doi:10.32474/ IGWHC.2018.01.000117

15. Heniwati, Thabrany H. Perbandingan Klaim Penyakit Katastropik Peserta Jaminan Kesehatan Nasional di Provinsi DKI Jakarta dan Nusa Tenggara Timur Tahun 2014. Jurnal Ekonomi Kesehatan Indonesia. 2016;1(2):1827. doi:10.7454/eki.v1i2.1771

16. Rathomi HS, Yulianto FA, Romadhona N. Dampak Program Jaminan Kesehatan Nasional Terhadap Utilisasi Layanan Kesehatan Pasien Kanker Serviks. Jurnal Kebijakan Kesehatan Indonesia. 2018;7(3):126-33. doi:10.22146/ jkki.38260

17. Chaparro CM, Suchdev PS. Anemia epidemiology, pathophysiology, and etiology in low- and middle-income countries. Ann N Y Acad Sci. 2019;1450(1):15-31. doi:10.1111/ nyas. 14092

18. Randi ML, Bertozzi I, Santarossa C, Cosi E, Lucente F, Bogoni G, et al. Prevalence and Causes of Anemia in Hospitalized Patients: Impact on Diseases Outcome. J Clin Med. 2020;9(4):1-9.doi:10.3390/jcm9040950

19. Thabrany H, Setiawan E, Puteri GC, Qodarina 
UK, Pujiastuti AS, Aisyah W, dkk. Studi evaluasi penyelenggaraan sistem rujukan berjenjang era JKN-KIS. Ringkasan riset JKN-KIS. 2017;03:18. [Internet] [diakses 20 Juli 2020]. Tersedia pada: https://bpjs-kesehatan.go.id/bpjs/arsip/ view/1193.
20. Lestari Handayani S, Pratiwi NL. Unit cost rumah sakit dan tarif INA-CBGS: sudahkah pembiayaan pelayanan kesehatan rumah sakit dibayar dengan layak? . Buletin Penelitian Sistem Kesehatan. 2018;21(4):219-27. doi:10.22435/hsr.v21i4.45 